\title{
Involvement of inducible nitric oxide synthase in stress-impaired testicular steroidogenesis
}

\author{
T S Kostic, S A Andric, D Maric, S S Stojilkovic ${ }^{\mathbf{1}}$ and R Kovacevic \\ Institute of Biology, Faculty of Sciences, University of Novi Sad, 21000 Novi Sad, Yugoslavia \\ ${ }^{1}$ Endocrinology and Reproduction Research Branch, NICHD, NIH, Bethesda, Maryland 20892-4510, USA \\ (Requests for offprints should be addressed to S Stojilkovic, SCS/ERRB/NICHD, Bldg. 49, Room 6A-36, 49 Convent Dr., Bethesda, Maryland 20892-4510, \\ USA; Email: stankos@helix.nih.gov)
}

\begin{abstract}
The immobilization stress induces an acute inhibition of testicular steroidogenesis that is mediated by the nitric oxide (NO) signaling pathway. Here we compared the effects of 2-h immobilization stress on in vivo and in vitro rat steroidogenesis at two time points, $0 \mathrm{~h}$ and $6 \mathrm{~h}$ after the end of the stress session. As expected, serum androgens and human chorionic gonadotropin (hCG)-stimulated progesterone and testosterone production by testicular tissue were inhibited at $0 \mathrm{~h}$, and also at the 6 -h time point. Both the acute and sustained inhibitions of in vitro steroidogenesis were accompanied by a significant increase in nitrite, a stable oxidation product of NO. To clarify which subtype of NO synthase (NOS) (constitutive (cNOS) or inducible (iNOS)) participates in down-regulation of testicular steroidogenesis, aminoguanidine hydrochloride (AG), a selective iNOS inhibitor, was employed. Intratesticular injection of AG prevented the sustained, but not the acute, stress-induced decrease in serum testosterone.
\end{abstract}

When added in vitro, it also prevented the sustained decrease in steroid production and increase in nitrite production by testicular tissue, both in a dose-dependent manner and with $\mathrm{EC}_{50}$ of about $50 \mu \mathrm{M}$. Furthermore, AG added in vivo and in vitro effectively blocked the sustained decrease in $3 \beta$-hydroxysteroid dehydrogenase (3ßHSD) and 17 $\alpha$-hydroxylase/C17-20 lyase (P450c17) activities. In all concentrations employed, AG did not affect serum androgens and in vitro steroid and nitrite production in unstressed animals. These results indicate that the NO signaling pathway participates in acute and sustained stress-induced down-regulation of testicular steroidogenesis, presumably through its direct action on $3 \beta \mathrm{HSD}$ and $\mathrm{P} 450 \mathrm{c} 17$. The acute NO production is controlled by cNOS and the sustained production of this messenger is controlled by iNOS.

Journal of Endocrinology (1999) 163, 409-416

\section{Introduction}

It is well established that acute immobilization stress (hereafter described as stress) impairs testicular steroidogenesis primarily at the testicular level. Immediately after the end of 2- to 3-h stress sessions, serum androgens, but not gonadotropins, are reduced (Orr \& Mann 1992, Srivastava et al. 1993, Akinbami et al. 1994, Maric et al. 1996, Kostic et al. 1997, 1998a). The stress-induced decrease in serum androgens is accompanied by significant changes in the activities of two steroidogenic enzymes, $3 \beta$-hydroxysteroid dehydrogenase (3ßHSD) and $17 \alpha-$ hydroxylase/C17-20 lyase (P450c17) (Srivastava et al. 1993, Akinbami et al. 1994, Maric et al. 1996, Kostic et al. 1997, 1998a). In vitro androgenesis by decapsulated testes from stressed rats exposed to human chorionic gonadotropin (hCG) for $3 \mathrm{~h}$ is also reduced, and this reduction coincides with an elevation in the testicular nitrite levels, a stable oxidation product of the nitric oxide pathway (Kostic et al. 1998b).
Nitric oxide (NO), a simple reactive free radical, acts as an intracellular and/or intercellular messenger in a number of tissues (Moncada et al. 1991). It is synthesized from $\mathrm{L}$-arginine in a reaction catalyzed by NO synthase (NOS), an enzyme that exists in several isoforms. The constitutive type of NOS (cNOS) is a calcium/calmodulin-dependent enzyme and is expressed in a variety of tissues, including human Leydig cells (Davidoff et al. 1995). The inducible NOS (iNOS) is expressed in rat Leydig cells (Tatsumi et al. 1997), as well as in rat Sertoli cells (Stephan et al. 1995). In addition, cNOS is expressed in the vascular endothelium of the rat testes (Burnett et al. 1995), whereas iNOS could be induced in macrophages, cells that represent a potential source of $\mathrm{NO}$ in the interstitium compartment of the testes (Stuehr et al. 1991). Other studies have shown that $\mathrm{NO}$ acts as an autocrine/paracrine messenger in the local regulation of testicular steroidogenesis in normal rats. A cNOS inhibitor, added in vitro, increases both basal and hCG-stimulated testosterone production (Welch et al. 1995). Conversely, several NO donors 
inhibit hCG-stimulated steroidogenesis in vitro in a dosedependent manner in both MA-10 immortalized cells and in Leydig cells from normal rats and mice (Punta et al. 1996, Pomerantz \& Petelka 1998).

Here, we studied the acute and sustained effects of stress on testicular steroidogenesis in vivo and in vitro and the importance of the NO signaling pathway in this inhibition. The focus of these investigations was on the role of iNOS-derived NO in acute and sustained stress-induced down-regulation of steroidogenesis. Therefore, in order to prevent the possible participation of iNOS in NO production in vivo, 2-h stress was accompanied or followed by two bilateral intratesticular injections of a relatively selective iNOS inhibitor, aminoguanidine (AG) during the post-stress period. Animals were either killed immediately or $6 \mathrm{~h}$ after the end of the stress session. The second time point was based on experiments by Tatsumi et al. (1997), who showed that $6-8 \mathrm{~h}$ is a sufficient time for the expression of iNOS mRNA and the synthesis of this enzyme in target tissues. In the second series of experiments, we analyzed the concentration dependence of AG on sustained stress-induced down- and up-regulation of in vitro steroidogenesis and nitrite production respectively.

\section{Materials and Methods}

\section{Chemicals}

Anti-testosterone-11-BSA serum \#250 and antiprogesterone-11-BSA serum \#337 were kindly supplied by G D Niswender (Colorado State University, Fort Collins, CO, USA). Medium 199 was purchased from GIBCO Laboratories (Gaithersburg, MD, USA), testosterone and progesterone were obtained from New England Nuclear (Boston, MA, USA). All other chemicals were obtained from Sigma (St Louis, MO, USA).

\section{Animals and treatments}

Experiments were performed in adult male Wistar rats (about $250 \mathrm{~g}$ ) bred in our laboratory and raised under controlled environmental conditions (temperature $22 \pm$ $2{ }^{\circ} \mathrm{C} ; 14 \mathrm{~h}$ light $/ 10 \mathrm{~h}$ darkness) with food and water available ad libitum. The animals were handled daily for one week prior to experiments. A group of rats was then subjected to 2-h immobilization stress (Kvetnansky et al. 1970), starting at $0530 \mathrm{~h}$, whereas control animals were left undisturbed. The first group of unstressed and stressed animals was killed by decapitation immediately after the end of the stress session $(0730 \mathrm{~h})$, and the second group $6 \mathrm{~h}$ later $(1330 \mathrm{~h})$. To examine the possible involvement of the iNOS-NO signaling system in stress-induced downregulation of testicular steroidogenesis, stressed and unstressed rats were treated with AG or saline. In the rats killed immediately after the end of the stress session, two bilateral intratesticular injections of AG (2 mg/testis) or saline were applied at the beginning of the immobilization period and $1.5 \mathrm{~h}$ later. In another group of rats, AG or saline was applied during the post-stress period; the first injection was $4 \mathrm{~h}$ after the end of the stress session and the second was $1.5 \mathrm{~h}$ later. Unstressed rats were treated with AG or saline at the same time as the stressed rats. These groups were killed $6 \mathrm{~h}$ after the end of the 2-h stress session. For in vitro experiments, the left testes were used for hemitestes preparations and the right testes for the preparations of post-mitochondrial testicular fractions. All experiments were approved by the Local Animal Ethical Committee of the University of Novi Sad and were conducted in accordance with the principles and procedures of the NIH Guide for Care and Use of Laboratory Animals.

\section{Hemitestis incubations and assays for hormones and nitrite}

Testes from stressed and unstressed rats were quickly removed and decapsulated hemitestes were incubated individually in vials containing hCG $(10 \mathrm{ng} / \mathrm{ml})$ and AG $(0,1,5 \mathrm{mM})$ in a total of $2 \mathrm{ml}$ medium 199 enriched with $0 \cdot 1 \%$ bovine serum albumin (BSA). Following incubation for $3 \mathrm{~h}$ in a shaking water bath $\left(34^{\circ} \mathrm{C}\right)$ oscillating at 100 cycles/min under an atmosphere of $95 \% \mathrm{O}_{2}-5 \% \mathrm{CO}_{2}$, incubation media were centrifuged for $10 \mathrm{~min}$ at $1500 \mathrm{~g}$. Individual samples of supernatants were stored at $-20{ }^{\circ} \mathrm{C}$ prior to measurement of progesterone, testosterone, and nitrite levels. Testosterone and progesterone were measured by radioimmunoassay. Because the antitestosterone serum showed 100\% cross-reactivity with dihydrotestosterone, values are referred to as testosterone + dihydrotestosterone $(\mathrm{T}+\mathrm{DHT})$ levels. All samples were assayed in a total of two assays (sensitivity $6 \mathrm{pg} /$ tube; intraand interassay coefficients of variation $5-8 \%$ and $7 \cdot 5 \%$ respectively). For progesterone measurements, each experiment was run in one assay (sensitivity $6 \mathrm{pg} /$ tube; intraand interassay coefficients of variation $6 \cdot 8 \%$ and $10 \cdot 7 \%$ respectively). For nitrite measurements, sample aliquots of $0.6 \mathrm{ml}$ were mixed with an equal volume of Greiss reagent containing $1 \%$ sulfanilamide and $0 \cdot 1 \%$ naphthylethylenediamine in $5 \%$ phosphoric acid. The mixture was then incubated at room temperature for $10 \mathrm{~min}$ and the absorbency was measured at $546 \mathrm{~nm}$ (Green et al. 1982). Nitrite concentrations were determined relative to a standard curve derived from increasing concentrations of sodium nitrite.

\section{Post-mitochondrial fractions and enzyme activities}

To prepare the post-mitochondrial fractions, testes were decapsulated and homogenized in $50 \mathrm{mM}$ phosphate buffer containing $0 \cdot 25 \mathrm{M}$ sucrose ( $\mathrm{pH} 7 \cdot 4$ ), using a glassglass homogenizer. After centrifugation $\left(4{ }^{\circ} \mathrm{C}\right.$ for $20 \mathrm{~min}$ at $1500 \mathrm{~g}$ ) the supernatants were mixed with dextran-coated 
charcoal in order to remove the endogenous steroids (Luzzani \& Soffientini 1979). The samples were centrifuged at $1500 \boldsymbol{g}$ for $10 \mathrm{~min}$ and supernatants were further centrifuged at $12000 \mathrm{~g}$ for $20 \mathrm{~min}$. Protein content in post-mitochondrial fractions was estimated by the Bradford (1976) method, using BSA as a standard. The P450c17 and 17 $\beta$-hydroxysteroid dehydrogenase $(17 \beta \mathrm{HSD})$ activities in post-mitochondrial fractions were measured as previously described and were estimated by conversion of progesterone to testosterone and $\Delta^{4}$-androstenedione to testosterone respectively (Kostic et al. 1997). Briefly, in the final volume of $0.25 \mathrm{ml}$, the incubation solution contained $10 \mu \mathrm{M}$ steroidcorresponding substrates, $1 \mathrm{mM}$ NADPH, $0 \cdot 1 \mathrm{M}$ phosphate buffer $(\mathrm{pH} 7 \cdot 4$ ), and $0.1 \mathrm{ml}$ post-mitochondrial fractions. Mixtures were incubated for $15 \mathrm{~min}$ at $37^{\circ} \mathrm{C}$ in a shaking water bath in $95 \% \mathrm{O}_{2}-5 \% \mathrm{CO}_{2}$ atmosphere. The $3 \beta \mathrm{HSD}$ activity was estimated as previously described (Maric et al. 1996) through the conversion of pregnenolone to progesterone. The incubation solution, with a final volume of $2 \mathrm{ml}$, contained $25 \mu \mathrm{M}$ pregnenolone, $135 \mu \mathrm{M} \mathrm{NAD}^{+}, 100 \mathrm{mM}$ phosphate buffer ( $\mathrm{pH} 7 \cdot 4$ ), and $0.1 \mathrm{ml}$ post-mitochondrial fraction. Mixtures were incubated for $10 \mathrm{~min}$ at $37^{\circ} \mathrm{C}$ in a shaking water bath in an atmosphere of $95 \% \mathrm{O}_{2}-5 \% \mathrm{CO}_{2}$. The activities of P450c17 and 17ßHSD were measured in the presence of saturated concentrations of the corresponding substrates, whereas $3 \beta \mathrm{HSD}$ activity was measured in the presence of sub-saturating concentration of pregnenolone (the estimated $\left.K_{\mathrm{m}}=8.43 \pm 1.76 \mu \mathrm{M}\right)$. Selected incubation times were within temporal linearity of the enzyme activities. Enzyme reactions were initiated by the addition of $0.1 \mathrm{ml}$ post-mitochondrial fractions and terminated by placing the tubes in an ice-cold bath. The samples were stored at $-20{ }^{\circ} \mathrm{C}$ until assayed for progesterone and testosterone by RIA.

\section{Calculations}

The non-parametric Mann-Whitney test was used for statistical analysis of results, with $P<0.05$ or higher indicating a significant difference.

\section{Results}

Acute and sustained effects of immobilization stress on testicular steroidogenesis

To investigate the time-dependence of stress on serum androgens, animals were exposed to $2-\mathrm{h}$ immobilization and killed immediately (0-h time point) or $6 \mathrm{~h}$ after the end of stress session (6-h time point). As shown in Fig. 1, left panel, a significant decrease in serum testosterone levels was observed at the $0-\mathrm{h}$ time point. Six hours after the exposure to stress, serum testosterone was still reduced

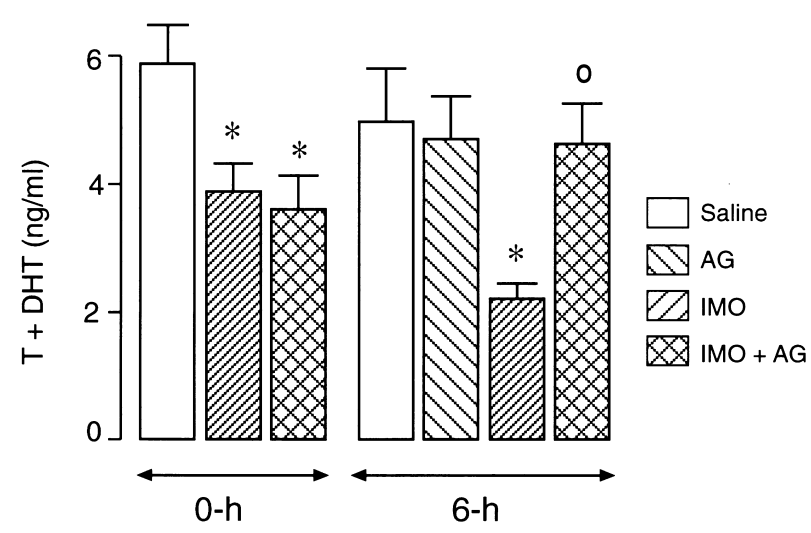

Figure 1 Effects of intratesticular injected aminoguanidine hydrochloride (AG) on immobilization (IMO) stress-induced inhibition of serum testosterone levels. (Left panel) Saline or AG ( $2 \mathrm{mg} /$ testis) were injected into each testis at the beginning and after $1.5 \mathrm{~h}$ of the stress session, and animals were killed $30 \mathrm{~min}$ after the second injection (0-h time point). (Right panel) Saline or AG was injected $4 \mathrm{~h}$ and $5.5 \mathrm{~h}$ after the end of the 2 -h stress session, and animals were killed 30 min after the second injection (6-h time point). Columns represent means \pm S.E.M., with six animals per group. ${ }^{*} P<0.05$ vs saline group; ${ }^{\circ} P<0.05$ vs IMO group.

and the level of inhibition was comparable to that observed in animals killed at the $0-\mathrm{h}$ time point (Fig. 1, right panel). The sustained inhibition of serum testosterone was consistently observed in several independent experiments. For example, in one such experiment serum androgens were reduced from $4 \cdot 19 \pm 0 \cdot 83 \mathrm{ng} / \mathrm{ml}$ (controls, $n=6$ ) to $1.61 \pm 0.46 \mathrm{ng} / \mathrm{ml}$ (stressed rats, $n=6 ; P<0 \cdot 05$ ).

In further studies, the steroidogenic capacity of testicular tissues from undisturbed and stressed animals was analyzed at both time points. For this purpose, hemitestes were stimulated with a supramaximal hCG concentration $(10 \mathrm{ng} / \mathrm{ml})$ for $3 \mathrm{~h}$ and progesterone and testosterone levels were measured in incubation medium. In parallel with the acute and sustained decrease in serum testosterone, hCGstimulated androgen production was significantly reduced (Table 1 and Fig. 2A, right panel). In testicular tissue from animals killed $6 \mathrm{~h}$ after exposure to stress, progesterone production was also significantly reduced compared with

Table 1 Effect of immobilization stress (IMO) and intratesticular AG treatment on the hCG-stimulated testosterone and nitrite production by hemitestes. Data shown are means \pm S.E.M. of $10-12$ hemitestes

\begin{tabular}{llll} 
& T+DHT $(\mu \mathrm{g} / \mathrm{g})$ & & Nitrite $(\mathrm{nmol} / \mathrm{g})$ \\
\cline { 2 - 2 } $\begin{array}{lll}\text { Treatment } \\
\text { Control }\end{array}$ & $2 \cdot 48 \pm 0 \cdot 12$ & & $110 \cdot 70 \pm 8 \cdot 24$ \\
IMO & $2 \cdot 04 \pm 0 \cdot 10^{*}$ & & $139 \cdot 70 \pm 6 \cdot 06^{*}$ \\
IMO+AG & $2 \cdot 02 \pm 0 \cdot 12^{*}$ & & $142 \cdot 71 \pm 5 \cdot 96^{*}$
\end{tabular}

Saline or AG (2 mg/testis) was injected into each testis prior to and $1.5 \mathrm{~h}$ after the start of the immobilization (IMO) period. Animals were killed at the end of the 2-h IMO session. Hemitestes were incubated for $3 \mathrm{~h}$ in the presence of $10 \mathrm{ng} / \mathrm{ml} \mathrm{hCG}$. ${ }^{*} P<0 \cdot 05$ vs controls. 


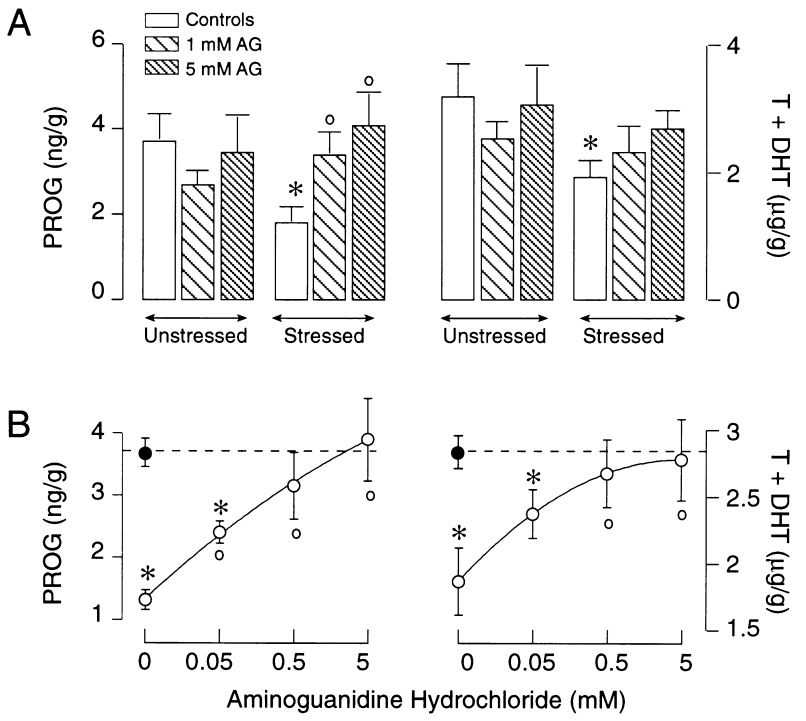

Figure 2 Effects of aminoguanidine hydrochloride (AG) on the in vitro hCG-stimulated progesterone (left panels) and testosterone (right panels) production by testicular tissues from unstressed and stressed rats killed $6 \mathrm{~h}$ after the exposure to stress. Hemitestes were incubated for $3 \mathrm{~h}$ in hCG $(10 \mathrm{ng} / \mathrm{ml})$-containing medium 199 with or without AG. (A) Effects of high AG concentrations on in vitro steroidogenesis. Columns represent means \pm S.E.M. of $5-7$ hemitestes per group. ${ }^{\star} P<0.05$ vs unstressed controls; ${ }^{\circ} P<0 \cdot 05$ vs stressed controls. (B) Concentration-dependent effect of AG on progesterone and testosterone production by hemitestes. Data points represent means \pm S.E.M. of $6-8$ hemitestes per group. Closed circles and dashed lines, steroid production by testicular tissues from unstressed rats during 3-h incubation. Open circles, steroid production by testicular tissues from stressed rats. ${ }^{*} P<0 \cdot 05$ vs unstressed controls; ${ }^{\circ} P<0.05$ vs stressed controls.

the controls (Fig. 2A, left panel). The decreased capacity of testes from stressed animals to respond to hCG was accompanied by increased production of intratesticular $\mathrm{NO}$ in both groups. Table 1 illustrates that nitrite levels were significantly elevated in hemitestes from stressed animals killed immediately after the end of the stress session compared with controls. Nitrite levels were also elevated in testicular tissue from stressed rats $6 \mathrm{~h}$ after the end of the stress session (Fig. 3).

\section{Characterization of NOS enzymes involved in testicular stress responses}

To identify the NOS subtype(s) participating in acute and sustained delivery of $\mathrm{NO}$ in stressed animals and to analyze the coupling of the NO signaling pathway to steroidogenesis, AG, a relatively specific inhibitor of iNOS, was employed. In the first experiment, saline or AG (2 mg/ testis) was injected into each testis at the beginning and $1.5 \mathrm{~h}$ into the immobilization period, with the animals being killed at the end of the 2-h stress session. As shown in Fig. 1, left panel, AG injection did not prevent the

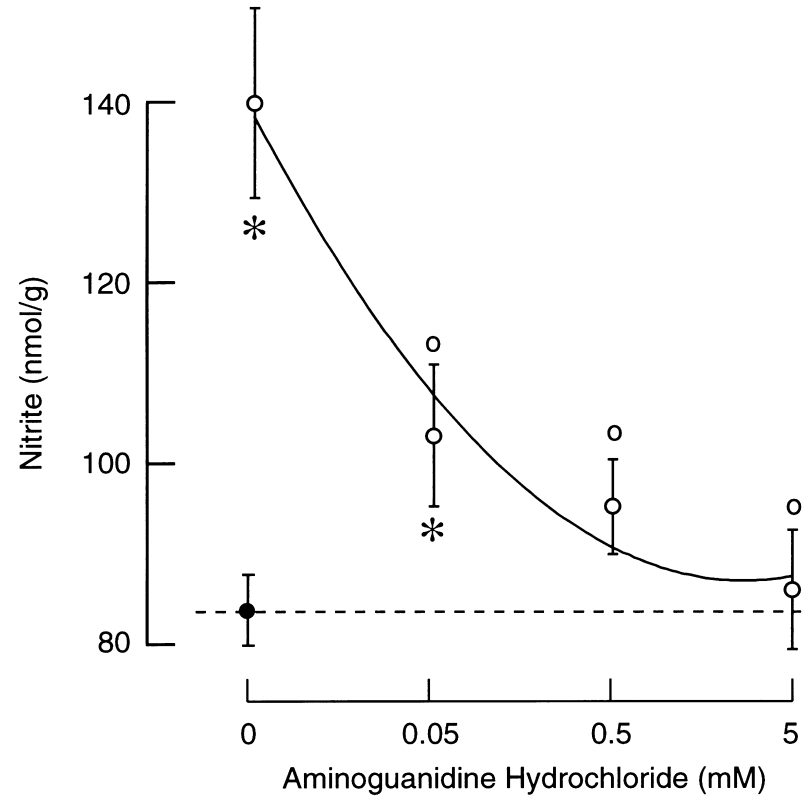

Figure 3 Concentration-dependent effects of aminoguanidine on in vitro nitrite production by testicular tissue from stressed rats. Animals were exposed to 2-h immobilization stress or left undisturbed, and were killed $6 \mathrm{~h}$ after the end of the stress period. Hemitestes obtained from unstressed and stressed rats were incubated for $3 \mathrm{~h}$, and nitrite levels were estimated in incubation medium after removal of testicular tissue (see Materials and Methods). Basal nitrite levels, present in the testicular tissue prior to incubation, were not subtracted. Data points represent means \pm S.E.M. of $6-8$ hemitestes per group. Closed circle and dashed line, nitrite production by testicular tissues from unstressed rats during the $3-\mathrm{h}$ incubation. Open circles, nitrite production by testicular tissues from stressed rats. ${ }^{\star} P<0.05$ vs unstressed controls; ${ }^{\circ} \mathrm{P}<0.05$ vs stressed controls.

stress-induced decrease in serum androgens. Furthermore, hCG-stimulated androgen production in vitro was comparable in testes from stressed and stress + AG-treated animals (Table 1). Finally, the stress-induced increase in nitrite concentration was not antagonized by AG (Table 1).

In the second experiment, AG was injected $4 \mathrm{~h}$ and $5.5 \mathrm{~h}$ after the end of the stress session. In contrast to the lack of effect of injected AG during the stress session, such treatment effectively antagonized the sustained stressinduced decrease in serum testosterone concentrations (Fig. 1, right panel). Added AG in vitro also antagonized the stress-induced down-regulation of steroid and nitrite productions, further suggesting the dependence of testicular steroidogenesis on the NO signaling pathway. Figure $2 \mathrm{~A}$ illustrates that $\mathrm{AG}$ in a high millimolar concentration range reduced the stress-induced inhibition of progesterone and testosterone production by testicular tissue from animals killed $6 \mathrm{~h}$ after the end of the stress session. In contrast, AG did not significantly change steroid production in unstressed animals, indicating the specificity of its in vitro actions. AG normalized the stress-induced 


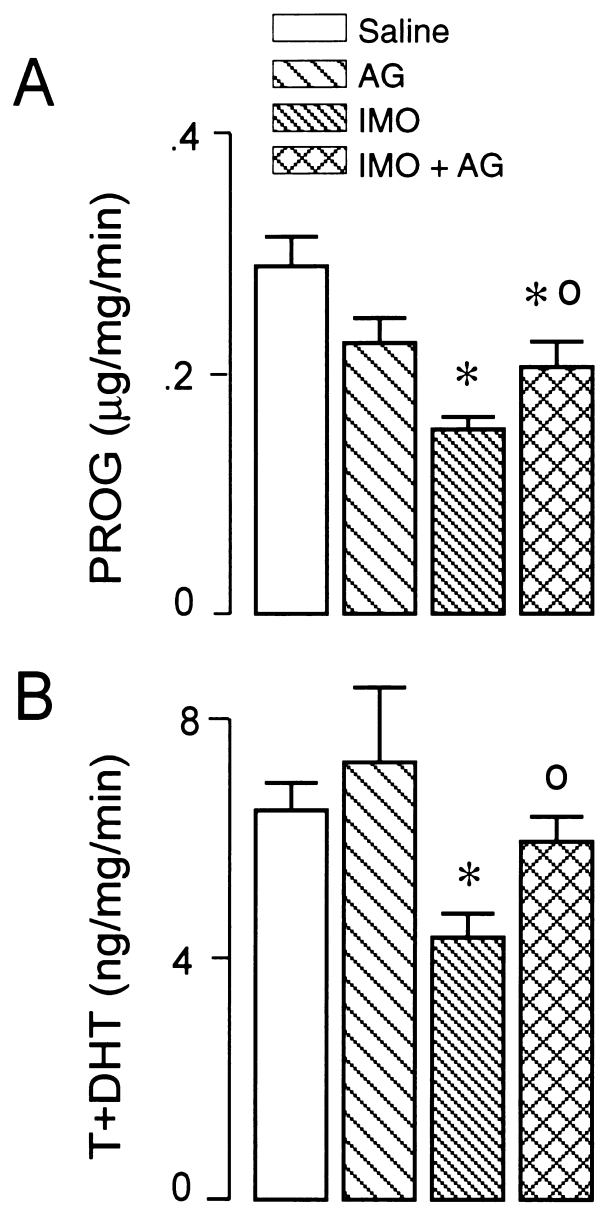

Figure 4 Effects of immobilization stress (IMO) and intratesticular aminoguanidine hydrochloride (AG) treatment on the activities of $3 \beta \mathrm{HSD}$ and P450c17 enzymes. Saline or AG (2 mg/testis) was injected into each testis $4 \mathrm{~h}$ and $5 \cdot 5 \mathrm{~h}$ after the end of IMO session, and animals were killed 30 min after the last injection. Individual post-mitochondrial testicular fractions (four assay replicates for each rat) were incubated in the presence of $25 \mu \mathrm{M}$ pregnenolone and $135 \mu \mathrm{M} \mathrm{NAD}{ }^{+}$for estimating the $3 \beta \mathrm{HSD}$ activity (A) and with $10 \mu \mathrm{M}$ progesterone and $1 \mathrm{mM} \mathrm{NADPH}$ for estimating the P450c17 activity (B). Columns represent means \pm S.E.M. of 6 rats per group. ${ }^{*} P<0 \cdot 05$ vs saline-treated unstressed rats; ${ }^{\circ} P<0.05$ vs saline-treated IMO-stressed rats.

down-regulation of progesterone and testosterone production in a dose-dependent manner, with an $\mathrm{EC}_{50}$ of about $50 \mu \mathrm{M}$. In vitro-added AG also normalized the production of testicular nitrites, with a comparable $\mathrm{EC}_{50}$ to that observed in steroid production (Fig. 3).

\section{Mechanism of down-regulation of testicular steroidogenesis by NO signaling pathway}

A decrease in serum testosterone observed in stressed rats was associated with a reduced 3ßHSD activity, as estimated by the conversion of pregnenolone to progesterone
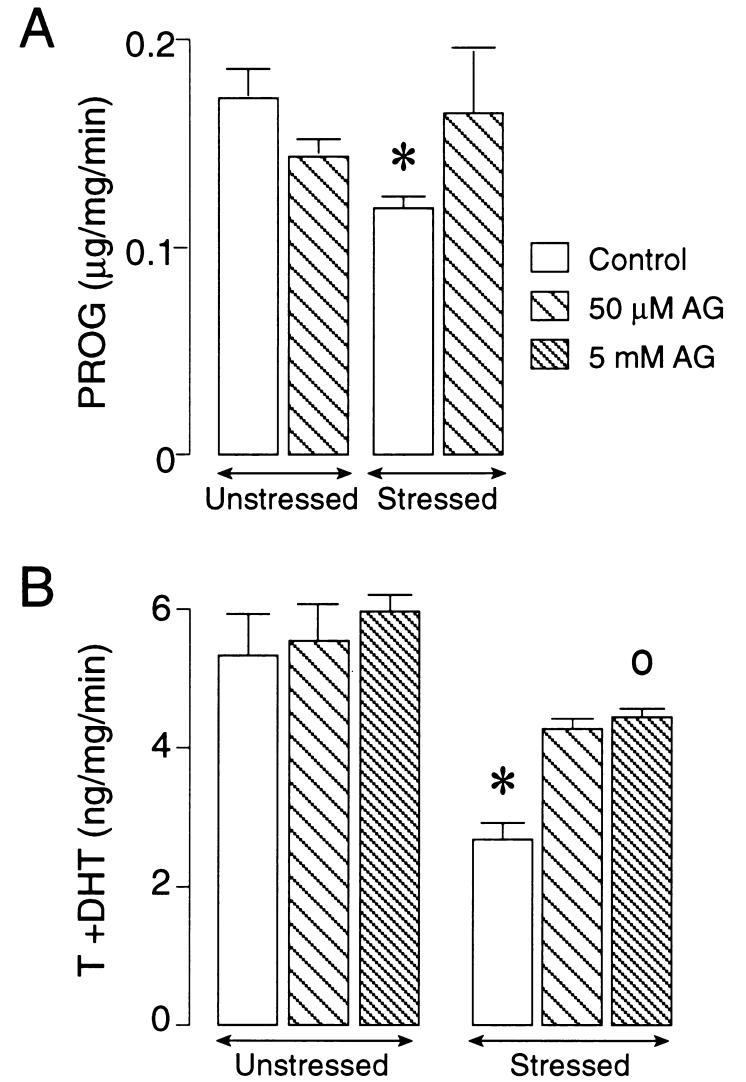

Figure 5 In vitro effects of aminoguanidine hydrochloride (AG) on the $3 \beta \mathrm{HSD}(\mathrm{A})$ and P450c17 (B) activities. Animals were exposed to 2 -h stress or left undisturbed and were killed $6 \mathrm{~h}$ after the end of the immobilization period. Enzyme activities were estimated in post-mitochondrial testicular fractions obtained from 6 IMOstressed and 6 unstressed rats. Incubations were carried out without (controls) or with $\mathrm{AG}(50 \mu \mathrm{M}$ and $5 \mathrm{mM})$ in incubation medium. Columns represent means \pm S.E.M. of $6-8$ replicates per group. ${ }^{*} P<0.05$ vs unstressed controls; ${ }^{\circ} P<0.05$ vs stressed controls.

in post-mitochondrial testicular fractions (Figs 4A and 5A). The conversion of progesterone to testosterone was also affected (Figs $4 \mathrm{~B}$ and $5 \mathrm{~B}$ ). In contrast, the conversion of $\Delta^{4}$-androstenedione to testosterone, mediated by the $17 \beta$ HSD activity, was not altered (Table 2). Bilateral intratesticular injections of AG during the post-stress period antagonized the stress-evoked decrease in $\mathrm{P} 450 \mathrm{c} 17$ activity (Fig. 4B) and partially recovered $3 \beta \mathrm{HSD}$ activity (Fig. 4A). Also, in vitro addition of $50 \mu \mathrm{M} \mathrm{AG}$ to the post-mitochondrial testicular fractions obtained from stressed rats normalized $3 \beta \mathrm{HSD}$ activity when compared with control values (Fig. 5A). In the concentrations investigated, AG had no effect on the activity of $3 \beta \mathrm{HSD}$ and $\mathrm{P} 450 \mathrm{c} 17$ when added to post-mitochondrial fractions from control animals. In addition, AG did not alter $17 \beta \mathrm{HSD}$ activity in preparations from control and stressed rats (Table 2). These results suggest that AG is capable of 
Table 2 Effects of immobilization stress (IMO) and in vitro addition of $\mathrm{AG}$ on the $17 \beta \mathrm{HSD}$ activity. Data shown are means \pm S.E.M. of 5-8 replicates

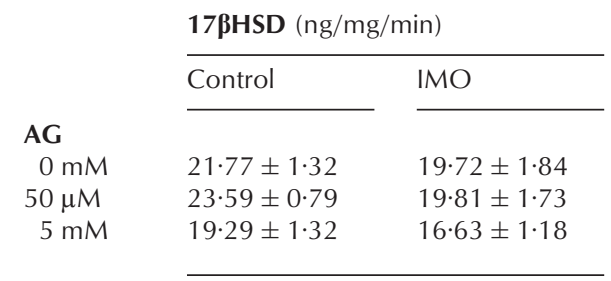

Animals were exposed to 2-h immobilization (IMO) stress or left undisturbed, and were killed $6 \mathrm{~h}$ after the end of the IMO period. The enzyme activity was estimated by conversion of $\Delta^{4}$-androstenedione to testosterone in a mixture of post-mitochondrial testicular fractions obtained from $6 \mathrm{IMO}$ and 6 control rats.

reversing the stress-induced decrease in $3 \beta \mathrm{HSD}$ and P450c17 activity in vivo and in vitro and, thereafter, normalizing the hCG-stimulated testosterone production.

\section{Discussion}

It is well established that a 2- to 3-h immobilization of rats is accompanied by a significant decrease in serum testosterone levels at the end of the stress session (Orr \& Mann 1992, Srivastava et al. 1993, Akinbami et al. 1994, Maric et al. 1996, Kostic et al. 1997). Here we show for the first time that stress-induced reduction in serum androgen levels is not a transient phenomenon, but lasts for several hours. Both the acute and sustained inhibition of serum testosterone was accompanied by inhibition of in vitro steroidogenesis. In our experiments, a supramaximal concentration of hCG $(10 \mathrm{ng} / \mathrm{ml})$ was employed, indicating that the steroidogenic capacity of testicular tissue was reduced in stressed animals at both time points, $0 \mathrm{~h}$ and $6 \mathrm{~h}$ after the end of the stress session. This is in accord with the view that stress-induced down-regulation of testicular steroidogenesis is, at least in part, independent of the status of serum gonadotropin levels (Kostic et al. 1997). The finding that both the acute and sustained inhibition of testicular steroidogenesis is accompanied by an increase in nitrite levels further suggests a role for the testicular NO signaling pathway in this process.

Initial evidence for the coupling of an $\mathrm{NO}$ signaling pathway to stress-mediated down-regulation of testicular steroidogenesis was obtained in experiments with L-NAME. Intratesticular injection of this non-selective NOS inhibitor partially antagonized the increase in intratesticular nitrite levels, and normalized in vitro hCGstimulated testosterone in stressed animals (Kostic et al. 1998b). This inhibitor added in vitro also increased basal and hCG-stimulated testosterone production in unstressed animals (Welch et al. 1995). In contrast to L-NAME, intratesticular injection of AG was ineffective in preventing the acute stress-induced fall in steroidogenesis and increase in nitrite production (Table 1). However, AG completely prevented the protracted inhibition of serum androgens (Fig. 1).

AG is commonly used in experiments as an effective NOS inhibitor. It specifically inhibits iNOS when employed in a micromolar concentration range, whereas at the submillimolar to millimolar concentration range it also inhibits cNOS (Misko et al. 1993, Griffiths et al. 1995, Mayer \& Andrew 1998). The finding that AG protects the sustained, but not the acute, decrease in serum androgens suggests that cNOS derives elevated NO during the stress period and iNOS during the post-stress period. More conclusive evidence for the participation of iNOS in sustained delivery of $\mathrm{NO}$ and inhibition of steroidogenesis was obtained when AG was added in vitro in different concentrations. Both $\mathrm{NO}$ and steroid production by hemitestes (Figs 2 and 3 ) and steroidogenesis by postmitochondrial testicular fractions (Fig. 5) were significantly affected by $50 \mu \mathrm{M}$ AG, a concentration that is ineffective in inhibiting cNOS.

The finding that $A G$ protects the sustained, but not the acute, stress-induced inhibition of steroidogenesis is in accord with literature data on the time-course for expression of iNOS. Exposure of rat Leydig cells to interleukin $1 \beta$ (IL-1 $\beta$ ) markedly increased the expression of iNOS messenger RNA as early as $3 \mathrm{~h}$ after the addition of the cytokine to freshly isolated immature Leydig cells. This is accompanied by increased NO production $6 \mathrm{~h}$ after stimulation with IL-1 $\beta$ (Tatsumi et al. 1997). It has also been shown that the addition of IL- $1 \beta$ to primary culture of purified rat Leydig cells significantly inhibits hCGstimulated testosterone production as early as $8 \mathrm{~h}$ after stimulation with this lymphokine (Calkins et al. 1988). The early expression of iNOS is not unique to Leydig cells, having also been observed in other tissues (Yamada et al. 1999).

The results presented here also provide new information about the mechanism of coupling the NO signaling pathway to testicular steroidogenesis. The sustained stressinduced decrease in steroidogenic capacity of testicular tissue was accompanied by a decreased conversion of pregnenolone to progesterone (Figs 4 and 5). This particular conversion was estimated by measuring progesterone levels after a 10-min incubation of post-mitochondrial testicular fractions with pregnenolone and $\mathrm{NAD}^{+}$, but not NADPH. Since the activities of two enzymes - P450c17, which catalyzes the conversion of progesterone to $\Delta^{4}$-androstenedione, and $17 \beta \mathrm{HSD}$, which catalyzes the conversion of $\Delta^{4}$-androstenedione to testosterone - are critically dependent on NADPH as an obligatory coenzyme, the conversion of progesterone to testosterone in our conditions should not take place. In support of that, we have found that the levels of testosterone in the incubation medium of post-mitochondrial fractions from control animals were less than $0.45 \mathrm{ng} / \mathrm{mg}$ protein $/ \mathrm{min}$, 
whereas in the same samples the levels of progesterone were about $200 \mathrm{ng} / \mathrm{mg} / \mathrm{min}$ (T S Kostic, S A Andric \& $\mathrm{R}$ Kovacevic, unpublished observation). Thus, it is highly probable that $3 \beta \mathrm{HSD}$ activity is negatively controlled by the stress-activated NO signaling pathway. A similar idea has recently been suggested by others (Ahsan et al. 1997).

Our results also show a decreased conversion of progesterone to testosterone by post-mitochondrial fractions from stressed animals (Figs 4 and 5). In the same preparations, the conversion of $\Delta^{4}$-androstenedione to testosterone was not affected (Table 2). Others have shown that incubation of adult rat testis tissue with pregnenolone results in 17-hydroxy $(\mathrm{OH})$-pregnenolone, progesterone, and $17 \mathrm{OH}$-progesterone peak productions within 1-2 min, whereas androstenedione and testosterone make their appearance later. Although the levels of $17 \mathrm{OH}$-progesterone and $17 \mathrm{OH}$-pregnenolone in these experiments were of the same magnitude, the levels of $\Delta^{4}$-androstenedione were much higher than dehydroepiandrosterone, indicating that $17 \mathrm{OH}$-progesterone was a better substrate for lyase activity of P450c17 than 17OH-pregnenolone (Weusten et al. 1987). This is in agreement with well-known evidence that the $\Delta^{4}$ pathway is the dominant pathway in the adult rat testes (Chase \& Payne 1983). Together, these findings suggest that the testicular NO signaling pathway also inhibits the P450c17-controlled conversion of progesterone to $17 \mathrm{OH}$-progesterone.

In line with our findings, Pomerantz and Petelka (1998) showed that the inhibitory effect of $\mathrm{NO}$ on testosterone production in mouse Leydig cells occurs, at least in part, via inhibition of P450c17 activity. Their conclusion was based on the failure of intermediates of steroidogenesis (22R-hydroxycholesterol, pregnenolone, progesterone, $17 \mathrm{OH}$-pregnenolone and $17 \mathrm{OH}$-progesterone) to overcome the inhibition caused by S-nitroso- $\mathrm{N}$-acetyl penicillamin, an $\mathrm{NO}$ donor. Also, NO donors inhibit hCG-stimulated steroidogenesis in rat Leydig cells, as well as the conversion of cholesterol to pregnenolone which is catalyzed by the cholesterol side-chain cleavage enzyme P450 scc (Punta et al. 1996). Regarding the mechanism of action of $\mathrm{NO}$, it was suggested that this messenger inhibits the activity of cytochrome $\mathrm{P} 450$ enzymes by its binding to heme iron (Quaroni et al. 1996), or to the sulfhydryl groups in these enzymes (Snyder et al. 1996). It should also be mentioned that addition of S-nitroso- $\mathrm{N}$-acetyl penicillamin to mouse Leydig cells had no detectable effect on the expression of mRNA for key P450-associated steroidogenic enzymes. This finding by Pomerantz and Petelka (1998) further confirms the possibility that NO interacts directly with the Fe heme of the P450 enzymes, leading to profound inhibition of P450c17.

An important question raised by our experiments is which testicular cells produce $\mathrm{NO}$ during the acute and sustained stress actions? The residence of cNOS in vascular endothelial cells in the testis (Burnett et al. 1995) may indicate their role in acute down-regulation of steroidogenesis, by changing the testicular blood flow. Also, the presence of macrophages in interstitial tissue (Stuehr et al. 1991) and their ability to produce IL-1, which in turn stimulates NO production (Tatsumi et al. 1997), may suggest a role for these cells in the coupling of the stress signaling system to the testicular NO pathway. In accord with this, the co-culture of mouse Leydig cells with activated macrophages significantly reduces luteinizing hormone-stimulated androgen production and this inhibition is blocked by L-NAME (Pomerantz \& Petelka 1998). Since the cellular localization of iNOS activated by stress remains to be clarified, at the present time we cannot exclude other cell types, including Leydig cells per se, in the sustained production of NO.

In conclusion, our results demonstrate that immobilization stress leads to acute and sustained down-regulation of testicular steroidogenesis. Both phases in stress-induced inhibition are mediated by the intratesticular NO signaling pathway. The acute inhibition is controlled by the cNOSdependent pathway, whereas the sustained inhibition is controlled, at least in part, by the iNOS signaling pathway. The coupling of these signaling pathways to steroidogenesis is mediated by two testicular enzymes, $3 \beta \mathrm{HSD}$ and $\mathrm{P} 450 \mathrm{c} 17$.

\section{References}

Ahsan S, Lacey M \& Whitehead SA 1997 Interactions between interleukin-1 $\beta$, nitric oxide and prostaglandin $\mathrm{E}_{2}$ in the rat ovary: effect on steroidogenesis. European Journal of Endocrinology 137 293-300.

Akinbami MA, Taylor MF, Collins DC \& Mann DR 1994 Effect of a peripheral and central acting opioid antagonist on the testicular response to stress in rats. Neuroendocrinology 59 343-348.

Bradford MM 1976 A rapid and sensitive method for quantitation of microgram quantities of protein utilizing the principle of proteindye binding. Analytical Biochemistry 72 248-254.

Burnett AL, Ricker DD, Chamness SL, Maguire MP, Crone JK, Bredt DS, Snyder SH \& Chang TSK 1995 Localization of nitric oxide synthase in the reproductive organs of the male rat. Biology of Reproduction 52 1-7.

Calkins JH, Sigel MM, Nankin HR \& Lin T 1988 Interleukin-1 inhibits Leydig cell steroidogenesis in primary culture. Endocrinology 123 1605-1610.

Chase DJ \& Payne AH 1983 Changes in distribution and androgen production of Leydig cells of two populations during sexual maturation in the rat. Endocrinology 112 29-34.

Davidoff MS, Middendorff R, Mayer B \& Holstein AF 1995 Nitric oxide (NOS-I) in Leydig cells of the human testis. Archives of Histology and Cytology 58 17-30.

Green LC, Wagner AA, Glogowski J, Skipper PL, Wishnok JS \& Tannenbaum SR 1982 Analysis of nitrate, nitrite, and $\left[{ }^{15} \mathrm{~N}\right]$ nitrate in biological fluids. Analytical Biochemistry 126 131-138.

Griffiths MJD, Messent M, MacAllister RJ \& Evans TW 1995 Aminoguanidine selectively decreases cyclic GMP levels produced by inducible nitric oxide synthase. American Journal of Respiratory and Critical Care Medicine 152 1599-1604.

Kostic T, Andric S, Kovacevic R \& Maric D 1997 The effect of opioid antagonists in local regulation of testicular response to acute stress in adult rats. Steroids $\mathbf{6 2} 703-708$. 
Kostic T, Andric S, Kovacevic R \& Maric D 1998a The effect of acute stress and opioid antagonists on the activity of NADPH-P450 reductase in rat Leydig cells. Journal of Steroid Biochemistry and Molecular Biology 66 51-54.

Kostic T, Andric S, Kovacevic R \& Maric D 19986 The involvement of nitric oxide in stress-impaired testicular steroidogenesis. European Journal of Pharmacology 346 267-273.

Kvetnansky R, Weise VK \& Kopin IJ 1970 Elevation of adrenal tyrosine hydroxylase and phenyletanolamine-N-methyl transferase by repeated immobilization of rats. Endocrinology 87 744-749.

Luzzani F \& Soffientini A 1979 Studies of cytosol progestin-binding components in the utero-placental unit of pregnant hamster. Journal of Steroid Biochemistry and Molecular Biology 13 697-701.

Maric D, Kostic T \& Kovacevic R 1996 Effects of acute and chronic immobilization stress on rat Leydig cell steroidogenesis. Journal of Steroid Biochemistry and Molecular Biology 58 351-355.

Mayer B \& Andrew P 1998 Nitric oxide synthases: catalytic function and progress toward selective inhibition. Naunyn-Schmiedelberg's Archives of Pharmacology 358 127-133.

Misko TP, Moore WM, Kasten TP, Nickols GA, Corbett JA, Tilton RG, McDaniel ML, Williamson JR \& Currie MG 1993 Selective inhibition of the inducible nitric oxide synthase by aminoguanidine. European Journal of Pharmacology 233 119-125.

Moncada S, Palmer RMJ \& Higgs EA 1991 Nitric oxide: physiology, pathophysiology and pharmacology. Pharmacological Review $\mathbf{4 3}$ 109-142.

Orr TE \& Mann DR 1992 Role of glucocorticoids in the stressinduced suppression of testicular steroidogenesis in adult male rat. Hormones and Behavior 26 350-363.

Pomerantz DK \& Petelka V 1998 Nitric oxide is a mediator of the inhibitory effect of activated macrophages on production of androgen by the Leydig cell of the mouse. Endocrinology 139 922-931.

Punta KD, Charreau EH \& Pignataro OP 1996 Nitric oxide inhibits Leydig cell steroidogenesis. Endocrinology 137 5337-5343.

Quaroni L, Reglinski J, Wolf R \& Smith WE 1996 Interaction of nitrogen monoxide with cytochrome P-450 monitored by surfaceenhanced resonance Raman scattering. Biochimica et Biophysica Acta $12965-8$.
Snyder GD, Holmes RW, Bates JN \& Van Voorhis BJ 1996 Nitric oxide inhibits aromatase activity: mechanisms of action. Journal of Steroid Biochemistry and Molecular Biology 58 63-69.

Srivastava RK, Taylor MF \& Mann DR 1993 Effect of immobilization stress on plasma luteinizing hormone, testosterone, and corticosterone concentrations and $3 \beta$-hydroxysteroid dehydrogenase activity in the testis of adult rats. Proceedings of the Society for Experimental Biology and Medicine 204 231-235.

Stephan JP, Guillemois C, Jegou B \& Bauche F 1995 Nitric oxide production by Sertoli cells in response to cytokines and lipopolysaccharide. Biochemical and Biophysical Research Communications 213 218-224.

Stuehr DJ, Cho Hj, Kwon NS, Weise MF \& Nathan CF 1991 Purification and characterization of the cytokine-induced macrophage nitric oxide synthase: an FAD- and FMN-containig flavoprotein. Proceedings of the National Academy of Sciences of the USA 88 7773-7777.

Tatsumi N, Fujisawa M, Kanzaki M, Okuda Y, Okada H, Arakawa S \& Kamodona S 1997 Nitric oxide production by cultured rat Leydig cells. Endocrinology 138 994-998.

Welch C, Watson ME, Poth M, Hong T \& Francis GL 1995 Evidence to suggest nitric oxide is an interstitial regulation of Leydig cell steroidogenesis. Metabolism 44 234-238.

Weusten JJAM, Smals AGH, Hofman JA, Kloppenborg PWC \& Benrad TJ 1987 Early time sequence in pregnenolone metabolism to testosterone in homogenates of human and rat testis. Endocrinology 120 1909-1913.

Yamada K, Komori Y, Tanaka T, Senzaki K, Nikai T, Sugihara H, Kameyama T \& Nabeshima T 1999 Brain dysfunction associated with an induction of nitric oxide synthase following an intracerebral injection of lipopolysaccharide in rats. Neuroscience $\mathbf{8 8}$ 281-294.

Received 17 February 1999

Revised manuscript received 10 June 1999

Accepted 19 July 1999 